\title{
Biotin studies in pigs
}

\author{
5. The post-ileal absorption of biotin \\ BY J. S. KOPINSKI, JANE LEIBHOLZ* AND R. J. LOVE \\ Department of Animal Husbandry, University of Sydney, Camden, \\ New South Wales 2570, Australia
}

(Received 22 September 1988 - Accepted 14 June 1989)

\begin{abstract}
Six pigs were given a biotin-deficient diet $(10 \mu \mathrm{g}$ biotin $/ \mathrm{kg})$ for 14 weeks. The pigs were given the same diet for a further $42 \mathrm{~d}$ with one of three biotin treatments: no supplement, $400 \mu \mathrm{g}$ biotin/d given orally, $400 \mu \mathrm{g}$ biotin/d infused into the caecum. The concentrations of biotin in the liver, kidney and heart, at the conclusion of $42 \mathrm{~d}$ were greater in the pigs given the oral biotin supplement than in the unsupplemented pigs. The values for the pigs given the caecal infusion of biotin were intermediate. The excretion of biotin in faeces was increased from 35 to $101 \mu \mathrm{g} / \mathrm{d}$ by the caecal biotin infusion, and the urinary excretion was increased from 35 to $83 \mu \mathrm{g} / \mathrm{d}$. The oral dose of biotin increased urinary biotin excretion from 35 to $345 \mu \mathrm{g} / \mathrm{d}$, but there was no change in faecal biotin exeretion. Two pigs were fitted with ileal cannulas and catheters in the vena cava. The pigs were given a dose of $\left[{ }^{14} \mathrm{Cl}\right.$ biotin either into the caecum, when the ileum was occluded by a bladder catheter, or orally. $\left.\right|^{14} \mathrm{C} \mid$ biotin was measured in the urine and plasma and showed that post-ileal biotin absorption was $8 \%$ as efficient as the absorption of biotin after oral dosing.
\end{abstract}

Biotin absorption : Pig

There is limited information on the absorption and excretion of biotin in pigs. H. R. Glattli (unpublished results quoted by Tagwerker, 1978) showed that orally administered synthetic biotin was rapidly absorbed, while Kopinski et al. (1989a) found that the major site of absorption was the duodenum. L. Volker and co-workers (unpublished results quoted by Tagwerker, 1978) found that about $22 \%$ of the biotin administered orally to pigs was excreted via the kidney. In the rat, biotin was partially oxidized in the liver and partially excreted in urine in a matter of hours (McCormick, 1975).

It has also been shown that the faecal excretion of biotin in pigs is independent of the biotin intake in feed (Kopinski \& Leibholz, 1989). However, the excretion of biotin in faeces is dependent on the composition of the feeds given to the pigs (Kopinski et al. 1989 $\mathrm{b}$, c). The reason for this effect may be the influence of dietary components on the microbial fermentation in the hind-gut.

The present experiment was designed to clarify whether there is any post-ileal absorption of biotin and to compare quantitatively post-ileal absorption of biotin with biotin absorption occurring after its oral administration.

\section{MATERIALS AND METHODS}

$$
\text { Expt } 1
$$

Animals and diets. Six Landrace-Large White pigs which had been given a maize flour and casein-based diet containing $10 \mu \mathrm{g}$ biotin $/ \mathrm{kg}$ for 14 weeks (from $2 \mathrm{~d}$ of age) were allotted 
Table 1. Composition of diet $(\mathrm{g} / \mathrm{kg})$

\begin{tabular}{lr}
\hline Dietary ingredient & $729 \cdot 2$ \\
Maize flour & $186 \cdot 2$ \\
Casein & $27 \cdot 0$ \\
Dicalcium phosphate & $3 \cdot 0$ \\
Limestone & $2 \cdot 1$ \\
Sodium chloride & $4 \cdot 4$ \\
Potassium chloride & $4 \cdot 1$ \\
Magnesium sulphate & $4 \cdot 0$ \\
Vitamins and trace minerals* & $20 \cdot 0$ \\
Maize oil & $20 \cdot 0$ \\
Calcium stearate & \\
\hline
\end{tabular}

* Supplying (mg/kg diet): 1.5 retinol, 0.025 cholecalciferol, $20 \alpha$-tocopherol, 2 menadione, $20 \mu \mathrm{g}$ cyanocobalamin, 1.5 thiamin, 6 riboflavin, 20 niacin, 10 pantothenic acid, 3 pyridoxine, 1000 choline, 3 folic acid, 0.1 biotin, 100 iron, 10 copper, 40 manganese, 70 zinc, 0.1 iodine, 0.1 selenium. Other additives $(\mathrm{mg} / \mathrm{kg})$ : 50 ethoxyquin.

to three treatments, with two pigs per treatment. The treatments were: (1) no biotin supplement, (2) $400 \mu \mathrm{g}$ biotin/d as an oral supplement, (3) $400 \mu \mathrm{g}$ biotin/d as a caecally infused supplement. All pigs were given $2.0 \mathrm{~kg} / \mathrm{d}$ of the pelleted diet shown in Table $1(10$ $\mu \mathrm{g}$ biotin $/ \mathrm{kg}$ ). Water was provided ad lib from nipple drinkers.

Surgery. Polyvinyl chloride tubing (i.d. $1.0 \mathrm{~mm}$ ) was inserted into the caecums of two pigs under surgical conditions (Hecker, 1974) and held in place by two sutures; Super Glue (Selleys, Sydney) was also used to bond and seal the entry point on the caecum. The tube was then passed under the skin, exteriorized on the mid-line and secured with elastic tape. Within $3 \mathrm{~d}$ both pigs were eating normal amounts of feed equivalent to pre-surgery intakes.

Infusion and oral dose of biotin. From $3 \mathrm{~d}$ after surgery the caecally cannulated pigs were infused continuously with $400 \mu \mathrm{g}$ biotin/d dissolved in $1600 \mathrm{ml}$ saline $(9 \mathrm{~g}$ sodium chloride/1). Biotin given orally was sprayed onto feed at $400 \mu \mathrm{g}$ biotin $/ 2 \mathrm{~kg}$ diet.

Collection procedure. Faeces were collected twice daily for $3 \mathrm{~d}$ before commencement of treatment and after $35 \mathrm{~d}$ of treatment. Faeces were frozen immediately at $-20^{\circ}$ then bulked and dried at $95^{\circ}$ for $24 \mathrm{~h}$ in a forced-air oven. Urine was collected during the same periods into buckets containing $100 \mathrm{ml} 1 \mathrm{M}$-sulphuric acid: the urine was removed daily, bulked and a subsample was frozen at $-20^{\circ}$ until analysed. On completion of the experiment, day 42 of treatment (determined by the accidental withdrawal of a caecal catheter by one pig), the pigs were killed and tissue samples were collected and frozen immediately at $-20^{\circ}$ until analysed.

\section{$\operatorname{Expt} 2$}

Animals and diet. Two $30 \mathrm{~kg}$ Landrace-Large White pigs were kept in metabolism cages for 2 weeks before surgery. The cages were in a room maintained at $26^{\circ}$. Fresh feed was offered daily and restricted to $1 \mathrm{~kg} / \mathrm{d}$; water was available ad lib. from nipple drinkers. The composition of the diet is shown in Table 1.

Surgery. Initially pigs were fitted with T-shaped cannulas in the terminal ileum, $20 \mathrm{~mm}$ from the ileo-caecal junction, as described previously (Kopinski et al. 1989 b). Then a polyvinyl chloride tube (i.d. $2.0 \mathrm{~mm}$ ) was passed through the T-shaped cannula and inserted about $100 \mathrm{~mm}$ into the caecum. The tube was then passed through a hole in the cannula lid; to secure the tube and prevent accidental withdrawal, elastic tape was wrapped around the tube just before its exit point on the cannula lid. Within $3 \mathrm{~d}$ pigs were eating 
normal amounts of feed equivalent to pre-surgery intakes. The caecal tube was flushed twice daily with saline to prevent blockage.

At $10 \mathrm{~d}$ after the fitting of the T-shaped cannulas, a blood catheter was introduced into the anterior vena cava via the cephalic vein following the procedure of Takken $\&$ Williams (1981). The catheter was stored in a nylon pouch sutured onto the back of the pig. The catheter was flushed with heparinized saline $(250 \mathrm{IU} / \mathrm{ml}$ saline $)$ at hourly intervals for the first $12 \mathrm{~h}$ and thereafter at six-hourly intervals until commencement of blood sampling.

Biotin administration. $\left[{ }^{14} \mathrm{C}\right.$ ]biotin (Amersham International plc, Amersham) $37 \mathrm{MBq}$, was dissolved in $80 \mathrm{ml}$ saline. The $\left[{ }^{14} \mathrm{C}\right]$ biotin solution was then divided into dose lots : 20 $\mathrm{ml}\left(1.1 \mathrm{mg}\right.$ or $9.25 \mathrm{MBq}\left[{ }^{14} \mathrm{C}\right]$ biotin) for each caecal dose and $10 \mathrm{ml}(0.55 \mathrm{mg}$ or $4.63 \mathrm{MBq}$ $\left[{ }^{14} \mathrm{C}\right]$ biotin) for each oral dose.

Before administration of the caecal dose of $\left[{ }^{14} \mathrm{C}\right]$ biotin through the caecal tube the terminal ileum was occluded at the T-shaped cannula site with an inflated bladder catheter. The oral dose was administered by wetting $100 \mathrm{~g}$ feed with the $\left[{ }^{14} \mathrm{C}\right]$ biotin solution; all feed was observed to be consumed within $5 \mathrm{~min}$.

Sample collection procedure. Blood samples $(10 \mathrm{ml})$ were collected from the blood catheters into heparinized tubes at $30 \mathrm{~min}$ intervals for $4 \mathrm{~h}$ after the dosing, then at $60 \mathrm{~min}$ intervals for a further $4 \mathrm{~h}$, after which samples of blood were collected at six-hourly intervals until completion of the experiment. Following each sampling period the blood was centrifuged at $3000 \mathrm{~g}$ for $10 \mathrm{~min}$ to separate the plasma, which was divided into $1 \mathrm{ml}$ portions which were immediately individually frozen at $-20^{\circ}$ and stored until analysed. Urine samples were collected over six-hourly intervals into trays containing $1 \mathrm{M}-\mathrm{H}_{2} \mathrm{SO}_{4}$. Urine volume was measured and then a sample was frozen at $-20^{\circ}$ until analysed.

Analytical methods. Feed, faeces and tissues were freeze-dried before analysis.

Biotin was analysed in the dry samples and in plasma and urine by the procedure of Hood (1977). Urine samples were filtered, neutralized with sodium hydroxide and then concentrated 20 -fold by drying overnight at $95^{\circ}$ before biotin analysis.

The radioactivity in plasma and urine samples $(1 \mathrm{ml})$ (from Expt 2) was measured using a scintillation cocktail of Teric X100-toluene (1:1 v/v) (Chapman \& Marcroft, 1971).

Statistical analysis. Experimental values were examined statistically by analysis of variance, and least significant difference $(P<0.05)$ was used to compare treatment means (Steel \& Torrie, 1980).

The decline in radioactivity (disintegrations/min $(\mathrm{dpm})$ per $\mathrm{ml}$ ) in the plasma was described by the model

$$
\mathrm{SR}_{t}=\mathrm{SR}_{01} e^{m_{1} t}+\mathrm{SR}_{02} e^{m_{2} t}
$$

where $\mathrm{SR}$ is specific radioactivity (counts/min per $\mathrm{ml}$ ) at time $t, \mathrm{SR}_{01}$ and $\mathrm{SR}_{02}$ are the zero time intercepts and $m_{1}$ and $m_{2}$ are the rate-constants for the decay curves.

The pool size was calculated as:

$$
\text { pool size }=\frac{\text { dose injected }}{\mathrm{SR}_{01}+\mathrm{SR}_{02}}
$$

\section{RESULTS}

\section{Expt 1}

The concentration of biotin in the tissues of pigs after 5 weeks of either oral or caecal infusion of biotin was higher than the concentration of biotin in the tissues of pigs 
Table 2. Expt 1. Biotin concentration in tissues (ng/g fresh weight) of pigs fed on a biotindeficient diet after 5 weeks of oral or caecal infusion of biotin or no biotin supplement*

(Mean values for two pigs)

\begin{tabular}{lcrc} 
& \multicolumn{3}{c}{ Tissue biotin content } \\
Treatment & Liver & Kidney & Heart \\
\hline No biotin supplement & 220 & 358 & 21 \\
$400 \mu \mathrm{g}$ biotin/d orally & 629 & 1201 & 78 \\
$400 \mu \mathrm{g}$ biotin/d caecally infused & 512 & 815 & 65 \\
SEM & 115.6 & 117.6 & 8.2 \\
\hline
\end{tabular}

* For details of diet and treatments, see Table 1 and p. 782.

Table 3. Expt 1. Faecal and urinary excretion of biotin $(\mu \mathrm{g} / d)$ by pigs fed on a biotindeficient diet before and after 5 weeks of oral or caecal infusion of biotin or no biotin supplement*

(Mean values for two pigs)

\begin{tabular}{|c|c|c|c|c|}
\hline \multirow[b]{2}{*}{ Treatment } & \multicolumn{2}{|c|}{ Faecal biotin excretion } & \multicolumn{2}{|c|}{ Urinary biotin excretion } \\
\hline & $\begin{array}{l}\text { Before } \\
\text { treatment }\end{array}$ & $\begin{array}{c}\text { After } \\
\text { treatment }\end{array}$ & $\begin{array}{l}\text { Before } \\
\text { treatment }\end{array}$ & $\begin{array}{c}\text { After } \\
\text { treatment }\end{array}$ \\
\hline $\begin{array}{l}\text { No biotin } \\
\text { supplement }\end{array}$ & 44 & 13 & 35 & 36 \\
\hline $400 \mu \mathrm{g}$ biotin $/ \mathrm{d}$ orally & 45 & 45 & 35 & 345 \\
\hline $\begin{array}{l}400 \mu \mathrm{g} \text { biotin } / \mathrm{d} \\
\text { caecally infused }\end{array}$ & 35 & 101 & 35 & 83 \\
\hline SEM & - & 5.9 & - & 33.9 \\
\hline
\end{tabular}

* For details of diet and treatments, see Table 1 and p. 782 .

maintained on the unsupplemented diet (Table 2). There was also a trend for the pigs to have higher tissue biotin concentrations when given biotin orally rather than by caecal infusion. In all pigs, irrespective of the treatment, the highest biotin concentrations were found in the kidneys.

Examination of the urine and faeces of pigs on the various treatments (Table 3) revealed similar urinary and faecal biotin excretion in all groups of pigs before commencement of the treatments. After 5 weeks, faecal biotin excretion was observed to decrease to one-third of the initial level in pigs given the unsupplemented diet. Pigs given the oral biotin supplement maintained faecal excretion of biotin at the same level as before commencement of treatment. A significant 3-fold increase in faecal biotin excretion was observed in pigs given biotin by caecal infusion. After 5 weeks of treatment, urinary biotin excretion in the pigs given the unsupplemented diet was the same as that observed before commencement of treatment. In the pigs given the oral supplement for 5 weeks there was a 10 -fold increase in urinary biotin excretion compared with the pre-treatment level. In the pigs given the caecal biotin supplement, urinary biotin excretion increased by nearly 2.5 -fold compared with the initial urinary biotin level. 
Table 4. Expt 1. Performance of pigs fed on a biotin-deficient diet, during 5 weeks of oral or caecal infusion of biotin or no biotin supplement*

(Mean values for two pigs)

\begin{tabular}{lcc}
\hline \hline Treatment & $\begin{array}{c}\text { Average } \\
\text { daily wt gain } \\
(\mathrm{g} / \mathrm{d})\end{array}$ & $\begin{array}{c}\text { Fed } \\
\text { conversion } \\
\text { ratio } \\
\text { (g intake/g wt gain) }\end{array}$ \\
\hline No biotin supplement & 446 & 3.65 \\
$400 \mu \mathrm{g}$ biotin/d orally & 591 & 2.64 \\
$400 \mu \mathrm{g}$ biotin/d caecally infused & 427 & 3.84 \\
SEM & 108.2 & 0.583 \\
\hline
\end{tabular}

* For details of diet and treatments, see Table 1 and p. 782

Table 5. Expt 1. Body and foot scores of pigs fed on a biotin-deficient diet before and after 5 weeks of oral or caecal infusion of biotin or no biotin supplement*

(Mean values for two pigs)

\begin{tabular}{|c|c|c|c|c|}
\hline \multirow[b]{2}{*}{ Treatment } & \multicolumn{2}{|c|}{ Foot score $\nmid$} & \multicolumn{2}{|c|}{ Body score $\neq$} \\
\hline & $\begin{array}{l}\text { Before } \\
\text { treatment }\end{array}$ & $\begin{array}{c}\text { After } \\
\text { treatment }\end{array}$ & $\begin{array}{l}\text { Before } \\
\text { treatment }\end{array}$ & $\begin{array}{c}\text { After } \\
\text { treatment }\end{array}$ \\
\hline $\begin{array}{l}\text { No biotin } \\
\text { supplement }\end{array}$ & $3 \cdot 5$ & $4 \cdot 5$ & 3 & 4 \\
\hline $400 \mu \mathrm{g} / \mathrm{d}$ orally biotin & $3 \cdot 5$ & $2 \cdot 0$ & 3 & 2 \\
\hline $400 \mu \mathrm{g}$ biotin/d caecally infused & 3.0 & $3 \cdot 5$ & 3 & 3 \\
\hline
\end{tabular}

* For details of diet and treatments, see Table 1 and p. 782.

+ Scale 0-5: 0 no obvious lesions, 5 severe lesions.

$\ddagger$ Scale 1-5: 1 good body condition, 5 very scaly with hair loss.

There were similar average daily weight gains and feed conversion ratios in pigs given no biotin supplement and the caecally infused biotin supplement (Table 4). The pigs given the oral biotin supplement showed a trend for greater daily weight gain and better feed conversion. Examination of the feet for lesions and of body condition after 5 weeks on the various treatments (Table 5) indicated that the pigs given the unsupplemented diet had an increase in the severity of hoof lesions, with a decline in body condition. Pigs given the caecal infusions displayed slightly more severe lesions, while body condition remained similar to pretreatment observations. The pigs given the oral biotin supplement displayed improved foot health, with fewer lesions of reduced severity; body condition was also observed to improve with biotin supplementation.

\section{Expt 2}

All radioactivity in the plasma and urine of the pigs given the oral or caecal infusion of $\left[{ }^{14} \mathrm{C}\right]$ biotin was $\left[{ }^{14} \mathrm{C}\right]$ biotin, since the radioactivity could be completely precipitated by the addition of avidin followed by protein precipitation. The radioactivity in the plasma of the 


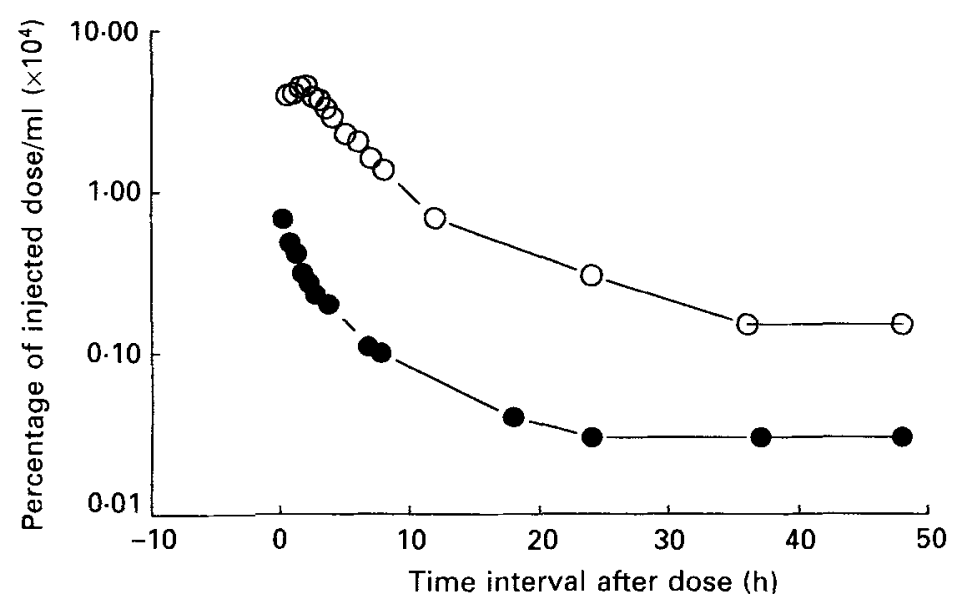

Fig. 1. Expt 2. The specific radioactivity of biotin in plasma after oral $(\mathrm{O}-\mathrm{O})$ and caecal

$\left[{ }^{1} \mathrm{C}\right]$ biotin (mean values for two pigs). For details of procedures, see p. 782 .

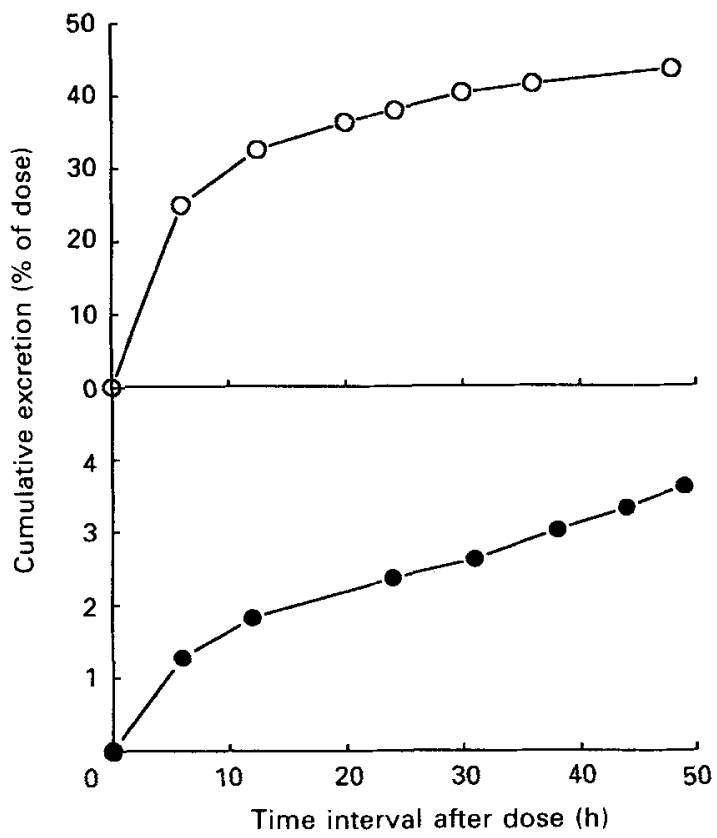

Fig. 2. Expt 2. The cummulative excretion of $\left[{ }^{14} \mathrm{C}\right]$ biotin in urine, expressed as a percentage of initial dose administered orally $(\mathrm{O})$ ) or into the caecum $(-)$ ) (mean values for two pigs). For details of procedures, see p. 782 .

two pigs after oral and caecal dosing with $\left[{ }^{14} \mathrm{C}\right]$ biotin is shown in Fig. 1. Following the oral dose of $\left[{ }^{14} \mathrm{C}\right]$ biotin $(0.5 \mathrm{mg})$, the radioactivity $(\mathrm{dpm})$ in the plasma was 790 after $30 \mathrm{~min}$ and increased to a maximum of 1100 after $90 \mathrm{~min}$. For the next $12 \mathrm{~h}$ the concentration of $\left[{ }^{14} \mathrm{C}\right]$ biotin in plasma declined linearly, with a calculated half-life of $7.2 \mathrm{~h}$. After $12 \mathrm{~h}$ there was no further significant change in the concentration of $\left[{ }^{14} \mathrm{C}\right]$ biotin in the plasma. Assuming a body water pool for the distribution of biotin of $30 \mathrm{~kg}(70 \%$ of body-weight), 
$14.1 \%$ of the oral dose of biotin appeared in the plasma. When the pigs were given the $\left[{ }^{14} \mathrm{C}\right]$ biotin $(1 \mathrm{mg})$ by caecal infusion, the radioactivity $(\mathrm{dpm})$ in the plasma reached 374 after $30 \mathrm{~min}$ and then decreased linearly (calculated half-life $1.3 \mathrm{~h}$ ). There was no significant change in the $\left[{ }^{14} \mathrm{C}\right]$ biotin in the plasma after $12 \mathrm{~h}$. A total of $1 \cdot 1 \%$ of the infused $\left[{ }^{14} \mathrm{C}\right]$ biotin appeared in the plasma.

The excretion of $\left[{ }^{14} \mathrm{C}\right]$ biotin in the urine (Fig. 2) showed that following oral dosing $15 \%$ of the dose was excreted within the first $6 \mathrm{~h}$, and a total of $44 \%$ of the entire dose was recovered in the urine over the $48 \mathrm{~h}$ of the experiment. When the pigs were given the radioactive biotin into the caecum, only $1 \%$ of the dose was recovered in the urine within the first $6 \mathrm{~h}$. A total of $3.6 \%$ of the entire dose given into the caecum was recovered in the urine over the $48 \mathrm{~h}$ of the experiment.

\section{DISCUSSION}

In our earlier experiment, it was found that the major site for the absorption of biotin was in the first quarter of the small intestine (Kopinski et al. 1989a). However, with the net increase in biotin content of digesta observed in the caecum and further down the intestinal tract in that same experiment, it was not possible to determine whether absorption of biotin occurred in the post-ileal digestive tract. The occurrence of symptoms of biotin deficiency in pigs despite such intestinal synthesis of biotin (Kopinski \& Leibholz, 1989) seemed to suggest little or no absorption of biotin from the caecum. The present experiment was formulated to resolve the question of whether any biotin absorption occurs from the postileal digestive tract.

Two approaches were used. Initially, unlabelled biotin was given, either orally or infused into the caecum, to pigs which had previously been maintained on a low-biotin diet for 14 weeks. The second approach was to use $\left[{ }^{14} \mathrm{C}\right]$ biotin, and to monitor the radioactivity in plasma and urine after a single caecal or oral dose.

The findings from the first experiment indicated that some absorption occurred from the post-ileal intestinal tract, as the concentration of biotin in tissues increased after 5 weeks of biotin supplementation via the caecum. The fact that the increase in tissue biotin concentration was not as great as that observed following oral supplementation suggests that, although absorption was occurring, it was not as efficient after caecal dosing as after oral dosing.

The excretion pattern observed after giving the various supplements indicated that oral biotin was absorbed and then primarily excreted in the urine, with no increase in faecal biotin excretion. However, pigs given the caecal dose of biotin have a different excretion pattern, with similar biotin excretion levels in both faeces and urine, indicating that some of the caecal dose was absorbed and then excreted in the urine, whereas the rest of the unabsorbed dose was excreted in the faeces. Barth et al. (1986) also found a substantial disappearance of the biotin (50-61\%) infused into the caecum of pigs. The pigs given no biotin supplement were observed to maintain a similar urinary biotin excretion and a reduction in the faecal biotin excretion which may be attributable to a reduction in feed intake by the animals severely affected by biotin deficiency lesions.

The performance of pigs during the 5 weeks of supplementation suggested that oral biotin would improve average daily weight gain and feed conversion ratio. However, this did not mean that biotin was required for growth, as the responses were primarily due to biotin reducing the severity of foot lesions which had resulted in a reluctance of the pigs to stand and move. The decrease in biotin deficiency lesions followed a similar pattern to that observed with tissue biotin concentrations, with the most observable improvements in the pigs dosed orally, the caecally-dosed pigs showing slight to no improvement in lesions, and 
pigs given the unsupplemented diet showing a further increase in the severity of the foot lesions.

A major problem in the results obtained from the present experiment was the possible influence of backflow of caecal contents into the ileum where biotin absorption could occur. This would result in a higher apparent aborption of the biotin infused into the caecum than that actually occurring in the hind-gut. To overcome this, during the second experiment with a single dose of $\left[{ }^{14} \mathrm{C}\right]$ biotin, the terminal ileum was occluded with a balloon catheter so that any observed absorption could definitely be attributed to post-ileal absorption.

In this second experiment, the radioactivity in the plasma reached a maximum $90 \mathrm{~min}$ after an oral dose of $\left[{ }^{14} \mathrm{C}\right]$ biotin in the feed. This would represent the time interval required for the meal to reach the intestine and its subsequent absorption. The radioactivity in the plasma was a maximum in the first sample taken $15 \mathrm{~min}$ after placing $\left[{ }^{14} \mathrm{C}\right]$ biotin in the caecum. The pool size of $\left[{ }^{14} \mathrm{C}\right]$ biotin in plasma after the caecal dose was $7 \cdot 7 \%$ of that after the oral dose of $\left[{ }^{14} \mathrm{C}\right]$ biotin. Similarily, the excretion of $\left[{ }^{14} \mathrm{C}\right]$ biotin in the urine of the pigs given the caecal dose was $8.4 \%$ of that of the pigs given the oral dose. This indicates an absorption of 0.08 of the caecally-infused biotin if orally-infused biotin is assessed to be 1.00. A value of $0 \cdot 18$ was estimated by Barth et al. (1986) from urinary excretion. However, in their experiment the ileum was not occluded and some biotin absorption may have occurred from the ileum with backflow from the caecum. Studies in humans with midtransverse colostomies have also shown less biotin absorption from infusion into the large intestine compared with oral administration (Sorrell et al. 1971).

The half life of $\left[{ }^{14} \mathrm{C}\right]$ biotin in the plasma after the caecal dose was less $(1 \cdot 3 \mathrm{~h})$ than that observed after the oral dose $(7 \cdot 2 \mathrm{~h})$. There are two explanations for this phenomenon. First, the caecal dose was given $48 \mathrm{~h}$ before the oral dose of $\left[{ }^{14} \mathrm{C}\right]$ biotin, and may have saturated the absorption sites for biotin in these biotin-deficient pigs. The second possibility is that the larger quantity of $\left[{ }^{14} \mathrm{C}\right]$ biotin absorbed from the oral dose results in a more rapid decline in plasma concentration.

The total recovery of $\left[{ }^{14} \mathrm{C}\right]$ biotin in the urine $(44 \%$ of oral dose) was higher than the observed value of L. Volker and co-workers (unpublished results, quoted by Tagwerker, 1978 ), of $22 \%$ of the oral dose.

The plateauing of the plasma ${ }^{14} \mathrm{C}$ curves (Fig. 1) after $12 \mathrm{~h}$ would indicate that the pig was very efficient at conserving the low levels of biotin remaining in the body after a single oral and caecal dose of $\left[{ }^{14} \mathrm{C}\right]$ biotin. This would agree with our earlier studies where it was shown that biotin deficiency symptoms take several weeks to develop (Kopinski et al. $1989 \mathrm{c}$ ). This may be due to the efficient action of the biotinidase enzyme as discussed by Kopinski et al. $(1989 \mathrm{c})$.

It may be concluded that absorption of free biotin in the post-ileal digestive tract is about $8 \%$ as efficient as that from a similar dose of biotin given orally. This value might have been lower if the absorption of dietary biotin or biotin from microbial synthesis had been measured. Moreover, absorption of biotin from backflow to the ileum was prevented in this experiment, and the ileum may be a site of biotin absorption in amounts sufficient to meet the pigs' requirement of biotin for growth (Kopinski \& Leibholz, 1989).

This study was made possible by the support of the Australian Pig Industry Research Committee and Hoffman-La Roche, Basle, Switzerland. The authors wish to thank Mrs R. Smith and Mr J. McClure for technical assistance. 
Chapman, D. I. \& Marcroft, J. (1971). The use of Triton X-100 in the liquid scintillation counting of ${ }^{14} \mathrm{C}$ with particular reference to plasma and urine. International Journal of Applied Radioactive Isotopes 22, $371-377$.

Hecker, J. F. (1974). Experimental Surgery on Small Ruminants. London: Butterworths.

Hood, R. L. (1977). Use of linear regression analysis in the isotope dilution assay of biotin. Analytical Biochemistry 79, 635-638.

Kopinski, J. S. \& Leibholz, J. (1989). Biotin studies in pigs. 2. The biotin requirement of the growing pig. British Journal of Nutrition 62, 761-766.

Kopinski, J. S., Leibholz, J. \& Bryden, W. L. (1989a). Biotin studies in pigs. 3. Biotin absorption and synthesis. British Journal of Nutrition 62,767-772.

Kopinski, J. S., Leibholz, J. \& Bryden, W. L. (1989b). Biotin studies in pigs. 4. Biotin availability in feedstuffs for pigs and chickens. British Journal of Nutrition 62, 773-780.

Kopinski, J. S., Leibholz, J., Bryden, W. L. \& Fogarty, A. C. (1989 c). Biotin studies in pigs. 1. Biotin deficiency in the young pig. British Journal of Nutrition 62, 751-759.

McCormick, D. B. (1975). Biotin. Nutrition Reviews 33, 97-102.

Sorrell, M. F., Frank, O., Thomson, A. D., Aquino, H. \& Baker, H. (1971). Absorption of vitamins from the large intestine in vivo. Nutrition Reports International 3, 143-148.

Steel, R. G. D. \& Torrie, J. H. (1980). Principles and Procedures of Statistics, 2nd ed. New York: McGraw Hill.

Tagwerker, F. J. (1978). Roche Information Service Bulletin no. 1675. Basle: Roche Products Ltd.

Takken, A. \& Williams, K. C. (1981). A simplified procedure for long-term catheterisation of the anterior vena cava in adult pigs. Australian Veterinary Journal 57, 17-20. 